\title{
Front Matter: Volume 10101
}

, "Front Matter: Volume 10101," Proc. SPIE 10101, Organic Photonic Materials and Devices XIX, 1010101 (5 May 2017); doi: 10.1117/12.2276174

SPIE. Event: SPIE OPTO, 2017, San Francisco, California, United States 


\title{
PROCEEDINGS OF SPIE
}

\section{Organic Photonic Materials and Devices XIX}

\author{
Christopher E. Tabor \\ François Kajzar \\ Toshikuni Kaino \\ Yasuhiro Koike \\ Editors
}

30 January-1 February 2017

San Francisco, California, United States

Sponsored and Published by

SPIE 
The papers in this volume were part of the technical conference cited on the cover and title page. Papers were selected and subject to review by the editors and conference program committee. Some conference presentations may not be available for publication. Additional papers and presentation recordings may be available online in the SPIE Digital Library at SPIEDigitallibrary.org.

The papers reflect the work and thoughts of the authors and are published herein as submitted. The publisher is not responsible for the validity of the information or for any outcomes resulting from reliance thereon.

Please use the following format to cite material from these proceedings:

Author(s), "Title of Paper," in Organic Photonic Materials and Devices XIX, edited by Christopher E. Tabor, François Kajzar, Toshikuni Kaino, Yasuhiro Koike, Proceedings of SPIE Vol. 10101 (SPIE, Bellingham, WA, 2017) Seven-digit Article CID Number.

ISSN: 0277-786X

ISSN: 1996-756X (electronic)

ISBN: 9781510606432

ISBN: 9781510606449 (electronic)

Published by

SPIE

P.O. Box 10, Bellingham, Washington 98227-0010 USA

Telephone +1 3606763290 (Pacific Time) · Fax +1 3606471445

SPIE.org

Copyright (c) 2017, Society of Photo-Optical Instrumentation Engineers.

Copying of material in this book for internal or personal use, or for the internal or personal use of specific clients, beyond the fair use provisions granted by the U.S. Copyright Law is authorized by SPIE subject to payment of copying fees. The Transactional Reporting Service base fee for this volume is $\$ 18.00$ per article (or portion thereof), which should be paid directly to the Copyright Clearance Center (CCC), 222 Rosewood Drive, Danvers, MA 01923. Payment may also be made electronically through CCC Online at copyright.com. Other copying for republication, resale, advertising or promotion, or any form of systematic or multiple reproduction of any material in this book is prohibited except with permission in writing from the publisher. The CCC fee code is $0277-786 \mathrm{X} / 17 / \$ 18.00$.

Printed in the United States of America.

Publication of record for individual papers is online in the SPIE Digital Library.

\section{SPIE. DIGITAL \\ SPIEDigitalLibrary.org}

Paper Numbering: Proceedings of SPIE follow an e-First publication model. A unique citation identifier (CID) number is assigned to each article at the time of publication. Utilization of CIDs allows articles to be fully citable as soon as they are published online, and connects the same identifier to all online and print versions of the publication. SPIE uses a seven-digit CID article numbering system structured as follows:

- The first five digits correspond to the SPIE volume number.

- The last two digits indicate publication order within the volume using a Base 36 numbering system employing both numerals and letters. These two-number sets start with 00, 01, 02, 03, 04, 05, 06, 07, 08, 09, OA, OB ... OZ, followed by 10-1Z, 20-2Z, etc. The CID Number appears on each page of the manuscript. 


\title{
Contents
}

\author{
$\checkmark$ Authors \\ vii Conference Committee
}

\section{NANOPHOTONICS I}

1010103 Random optical media based on hybrid organic-inorganic nanowires: multiple scattering, field localization, and light diffusion (Invited Paper) [10101-53]

OLEDS

$101010 \mathrm{C}$ Tuning of the emission color of organic light emitting diodes via smartly designed aluminum plasmonics [10101-11]

10101 OD Enhancing light extraction efficiency in MDMO-PPV based OLEDs by incorporating $\mathrm{SiO}_{2}-250 \mathrm{~nm}$ colloidal crystals [10101-12]

10101 OE Light coupling in polymer nanofibers: from single-photon emission to random lasing (Invited Paper) [10101-52]

\section{NANOPHOTONICS II}

10101 OK Single molecule-level study of donor-acceptor interactions and nanoscale environment in blends [10101-19]

10101 OL Graphene and silver-nanoprism dispersion for printing optically transparent electrodes [10101-20]

OPVs

$101010 M \quad$ Planar heterojunction perovskite solar cells fabricated by wet process (Invited Paper) [10101-21]

10101 OR Spectroscopic investigation of squaraine dyes [10101-13]

MATERIALS I

10101 OT Photoanisotropy in polarization-sensitive polymer materials based on the media with covalently-bonded components [10101-29]

10101 OU Fungi-derived pigments as sustainable organic (opto)electronic materials [10101-30] 
10101 OW Photoinduced (anomalous) dynamics of functionalized polymer chains: applications for Surface Relief Grating modelling (Invited Paper) [10101-32]

$101010 X \quad$ Flexible thin polymer waveguide Bragg grating sensor foils for strain sensing [10101-33]

10101 OY Multi-layered fabrication of large area PDMS flexible optical light guide sheets [10101-34]

$101010 Z$ Polymer optical fibers doped with organic materials as luminescent solar concentrator [10101-35]

\section{EO/NLO POLYMERS}

1010112 Effect of charge carrier blocking, surface resistance and electric field distribution on electric field poling of nonlinear optic polymers (Invited Paper) [10101-38]

\section{MATERIALS II}

1010116 Additive manufacturing of tunable lenses (3D Printing Best Paper Award) [10101-42]

1010117 Change of electric dipole moment in charge transfer transitions of ferrocene oligomers studied by ultrafast two-photon absorption [10101-43]

1010118 Additive manufacturing: a new approach to realize complex and unconventional optical components [10101-44]

\section{POSTER SESSION}

10101 1B Deep-blue light emission with a wide-bandgap naphthalene-derivative liquid organic semiconductor host [10101-48]

10101 1D Influences of device structures on microstructure-correlated photovoltaic characteristics of organic solar cells [10101-50] 


\section{Authors}

Numbers in the index correspond to the last two digits of the seven-digit citation identifier (CID) article numbering system used in Proceedings of SPIE. The first five digits reflect the volume number. Base 36 numbering is employed for the last two digits and indicates the order of articles within the volume. Numbers start with 00, 01, 02, 03, 04, 05, 06, 07, 08, 09, 0A, 0B...0Z, followed by 10-1Z, 20-2Z, etc.

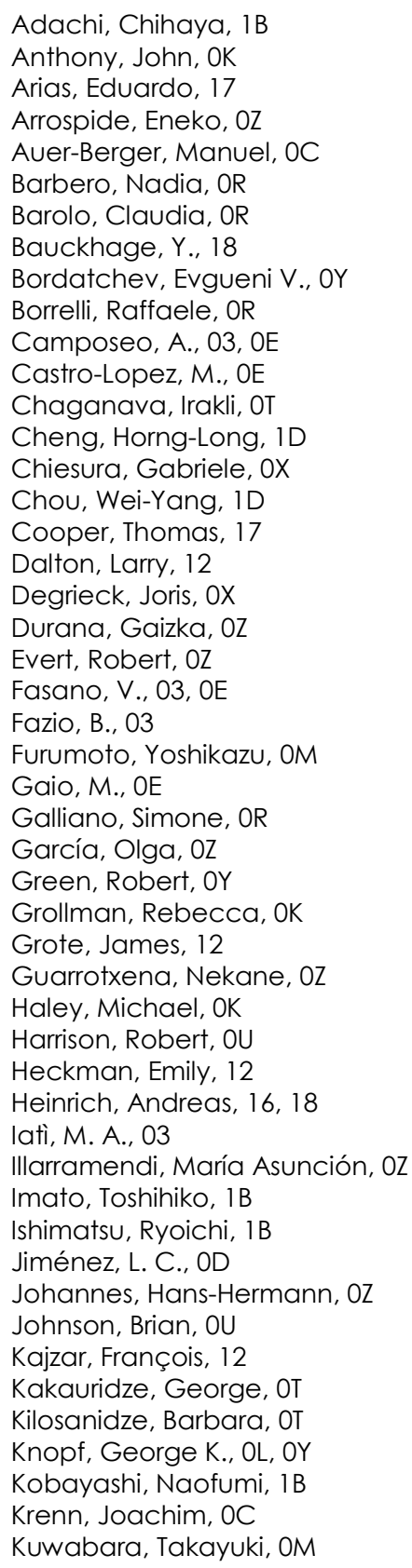

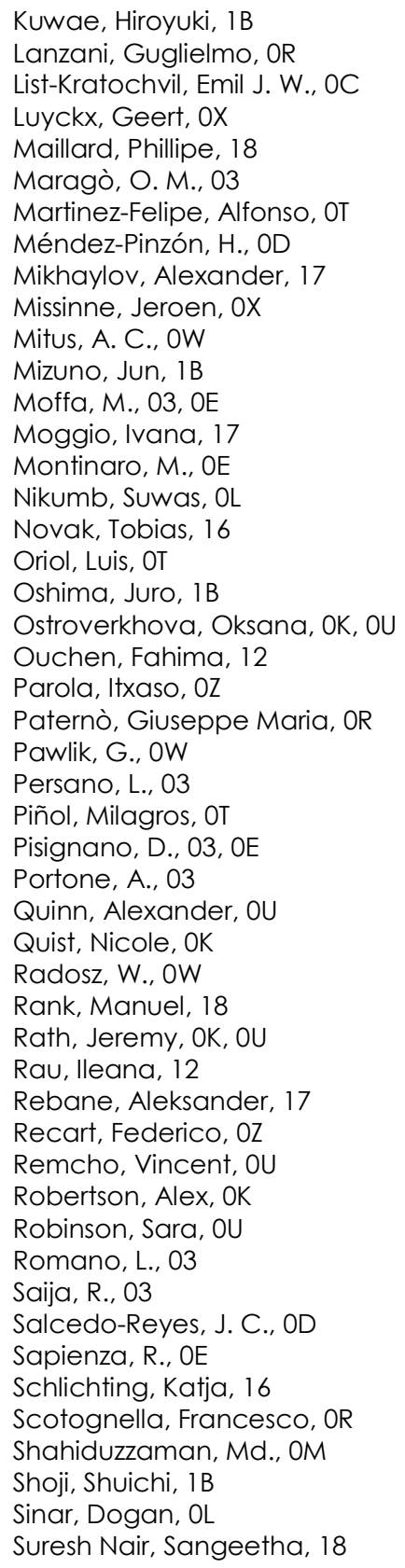


Taima, Tetsuya, OM

Takahashi, Kohshin, OM

Tashiro, Shuya, 1B

Teigell Benéitez, Nuria, OX

Tretnak, Veronika, OC

Trummal, Aleksander, 17

Tseng, Po-Tsung, 1D

Uudsemaa, Merle, 17

Van Steenberge, Geert, OX

Vázquez, J., OD

Weber, Genevieve, OU

Wenzl, Franz-Peter, 0C

Wu, Fu-Chiao, 1D

Wysoczanski, T., OW

Yamamoto, Kohei, OM

Yang, Cheng-Chi, 1D

Zaremba, Daniel, $\mathrm{OZ}$

Ziolo, Ronald, 17

Zubia, Joseba, $\mathrm{OZ}$

Proc. of SPIE Vol. 10101 1010101-6

Downloaded From: https://www.spiedigitallibrary.org/conference-proceedings-of-spie on 25 Apr 2023 Terms of Use: https://www.spiedigitallibrary.org/terms-of-use 


\section{Conference Committee}

Symposium Chairs

Jean-Emmanuel Broquin, IMEP-LAHC (France)

Shibin Jiang, AdValue Photonics, Inc. (United States)

Symposium Co-chairs

Connie J. Chang-Hasnain, University of California, Berkeley

(United States)

Graham T. Reed, Optoelectronics Research Centre, University of

Southampton (United Kingdom)

Program Track Chair

James G. Grote, Air Force Research Laboratory (United States)

Conference Chairs

Christopher E. Tabor, Air Force Research Laboratory (United States) François Kajzar, Universitatea Politehnica of Bucharest (Romania) Toshikuni Kaino, Tohoku University (Japan)

Yasuhiro Koike, Keio University (Japan)

\section{Conference Program Committee}

Chantal Andraud, Ecole Normale Supérieure de Lyon (France)

Werner J. Blau, Trinity College Dublin (Ireland)

Andreas Bräuer, Fraunhofer-Institut für Angewandte Optik und Feinmechanik (Germany)

Fabrice Charra, Commissariat à l'Énergie Atomique (France)

Beata J. Derkowska-Zielinska, Nicolaus Copernicus University (Poland)

Raluca Dinu, GigOptix, Inc. (United States)

Manfred Eich, Technische Universität Hamburg-Harburg (Germany)

Alain F. Fort, Institut de Physique et Chimie des Matériaux de Strasbourg (France)

James G. Grote, Air Force Research Laboratory (United States)

F. Kenneth Hopkins, Air Force Research Laboratory (United States)

Alex K. Y. Jen, University of Washington (United States)

Michael H. C. Jin, Johns Hopkins University Applied Physics Laboratory, LLC (United States)

Eunkyoung Kim, Yonsei University (Korea, Republic of)

Jang-Joo Kim, Seoul National University (Korea, Republic of) 
Nakjoong Kim, Hanyang University (Korea, Republic of)

Isabelle Ledoux-Rak, Ecole Normale Supérieure de Cachan (France)

Charles Y. C. Lee, Air Force Office of Scientific Research

(United States)

Kwang-Sup Lee, Hannam University (Korea, Republic of)

Misoon Y. Mah, Asian Office of Aerospace Research and

Development (Japan)

Seth R. Marder, Georgia Institute of Technology (United States)

Antoni C. Mitus, Wrocław University of Technology (Poland)

Jaroslaw Mysliwiec, Wrocław University of Technology (Poland)

Robert L. Nelson, Air Force Research Laboratory (United States)

Robert A. Norwood, College of Optical Sciences, The University of Arizona (United States)

Jean-Michel Nunzi, Queen's University (Canada)

Shuji Okada, Yamagata University (Japan)

Akira Otomo, National Institute of Information and Communications Technology (Japan)

lleana Rau, Universitatea Politehnica of Bucharest (Romania)

Niyazi Serdar Sariciftci, Johannes Kepler Universität Linz (Austria)

Devanand K. Shenoy, Defense Advanced Research Projects Agency

(United States)

Kenneth D. Singer, Case Western Reserve University (United States)

Attila A. Szep, Air Force Research Laboratory (United States)

Rebecca E. Taylor, Lockheed Martin Space Systems Company (United States)

Jeong-Weon Wu, Ewha Womans University (Korea, Republic of)

Shiyoshi Yokoyama, Kyushu University (Japan)

Roberto Zamboni, Istituto per la Sintesi Organica e la Fotoreattività (Italy)

Wei Zhou, Virginia Polytechnic Institute and State University

(United States)

\section{Session Chairs}

1 Nanophotonics I

Christopher E. Tabor, Air Force Research Laboratory (United States)

2 Biophotonics

André-Jean Attias, Université Pierre et Marie Curie (France)

3 OLEDS

Ifor D. W. Samuel, University of St. Andrews (United Kingdom)

4 Organic Semiconductors

Jang-Joo Kim, Seoul National University (Korea, Republic of) 
5 Nanophotonics II

Ileana Rau, Universitatea Politehnica of Bucharest (Romania)

6 OPVs

Christopher E. Tabor, Air Force Research Laboratory (United States)

7 Materials I

Kwang-Sup Lee, Hannam University (Korea, Republic of)

8 Waveguides/Fiber

Toshikuni Kaino, Tohoku University (Japan)

9 EO/NLO Polymers

Antoni C. Mitus, Wrocław University of Science and Technology (Poland)

10 Materials II

Kenneth D. Singer, Case Western Reserve University (United States) 
Proc. of SPIE Vol. 10101 1010101-10 Downloaded From: https://www.spiedigitallibrary.org/conference-proceedings-of-spie on 25 Apr 2023
Terms of Use: https://www.spiedigitallibrary.org/terms-of-use 